\title{
Introduction of alkali-labile units into lignin in transgenic plants by genetic engineering
}

\author{
Yasuyuki Ishikawa', Yukiko Tsuji, Kanna Sato', Amiu Shino², Yoshihiro Katayama ${ }^{3}$, Jun Kikuchi ${ }^{2}$, Hirofumi Hara ${ }^{4}$, \\ Shojiro Hishiyama ${ }^{5}$, Eiji Masai ${ }^{6}$, Shinya Kajita ${ }^{1 *}$ \\ From IUFRO Tree Biotechnology Conference 2011: From Genomes to Integration and Delivery \\ Arraial d Ajuda, Bahia, Brazil. 26 June - 2 July 2011
}

\section{Background}

Lignin is one of major components of plant secondary cell wall. In plant cell wall, it is synthesized via radical coupling of precursors such as $p$-coumaryl, coniferyl, and sinapyl alcohols. In early stage of the lignification, 8-O-4, 8-8' and 8-5' dimers are thought to be synthesized mainly from the precursors in the wall. A gramnegative bacterium, Shingobium sp. strain SYK-6 (hereafter refer to as SYK-6) is able to catabolize a wide variety of phenolic compounds including the lignin precursors by its unique enzymatic system. One of catabolic enzymes, LigD, catalyzes oxidation at alpha (benzyl) position of 8-O-4' dimers and forms carbonyl group at the position (Figure 1). This oxidation is the first step of catabolic pathway of 8-O-4' dimers in SYK-6. When we express LigD polypeptide in the cell wall of transgenic plants, the oxidative dimers will be expected to be generated and then incorporated into lignin polymer. In some past studies, it has been shown that the presence of carbonyl groups at the alpha position of aryl propane units in lignin greatly speeds up the rate of cleavage of beta-aryl ether linkages during kraft pulping condition $[1,2]$. In order to contribute to efficient and sustainable production of kraft pulp and the other biomass-derived products such as bioethanol, we introduced the $\operatorname{lig} D$ gene into Arabidopsis and hybrid aspen and tried to generate transgenic plants whose lignin can be easy to remove from hollocellulose fraction under alkaline conditions.

\footnotetext{
* Correspondence: kajita@cc.tuat.ac.jp

'Graduate School of Bio-Applications and Systems Engineering, Tokyo University of Agriculture and Technology, Koganei, Tokyo 184-8588, Japan Full list of author information is available at the end of the article
}

\section{Method}

Because of codon usage is significantly different between genes in plants and SYK-6, we chemically synthesized open reading frame (ORF) of the ligD gene for improving its expression in the transgenic plants. After addition of nucleotide sequence for apoplast-targeting signal peptide to the synthesized $\operatorname{lig} D$ ORF, it was introduced into Arabidopsis thaliana, tobacco BY-2 and hybrid aspen under the control of cauliflower mosaic virus $35 \mathrm{~S}$ promoter. LigD expression in the transgenic plants was monitored by Western blot analysis and enzymatic activity with crude extract prepared from each transgenic line. Preliminary analysis of lignin structure by 2D-NMR and nitrobenzene oxidation was also performed.

\section{Results and discussion}

At first we confirmed expression of the ligD transgene in Arabidopsis by Western blot analysis with antiserum against LigD polypeptide. Positive expressions of the ligD were detected in some of the transgenic plants

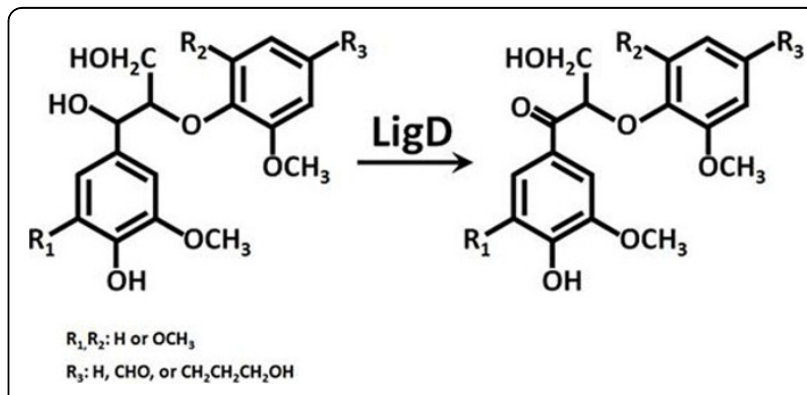

Figure 1 The reaction catalyzed by LigD. This bacterial enzyme catalyzes oxidation of benzyl position of 8-O-4' lignin dimers. Both of guaiacyl-guaiacyl and syringyl-syringyl dimers can be oxidized by the enzyme. 
analyzed. Enzymatic activities of LigD in crude extracts prepared from both cytosolic and apoplastic fractions of the transgenic Arabidopsis plants were also detected, but it was relatively higher in the latter case. As expected, 2D NMR $\left({ }^{1} \mathrm{H}_{-}{ }^{13} \mathrm{C}\right.$ HMQC) analysis suggests that the abundance of the alpha-keto (alpha carbonyl) structure in 8-O-4' units of lignin in the transgenic plants is relatively higher than that in the wild-type plant. Chemical compositions of lignin (syringyl/guaiacyl ratio) and neutral sugars could not be distinguishable between the transgenic and wild-type plants. Generation of transgenic hybrid aspen and its analysis are now in progress.

\section{Acknowledgements}

This research project was supported partly by the New Energy and Industrial Technology Development Organization (NEDO).

\section{Author details}

${ }^{1}$ Graduate School of Bio-Applications and Systems Engineering, Tokyo University of Agriculture and Technology, Koganei, Tokyo 184-8588, Japan. ${ }^{2}$ Metabolomics Research Group, RIKEN Plant Science Center, Yokohama, Kanagawa 230-0045, Japan. ${ }^{3}$ Department of Forest Science and Resource, College of Bioresource Sciences, Nihon University, Fujisawa, Kanagawa 2528510, Japan. ${ }^{4}$ Department of Biomedical Engineering, Okayama University of Science, Okayama, Okayama 700-0005, Japan. ${ }^{5}$ Department of Biomass Chemistry, Forestry and Forest Products Research Institute, Tsukuba, Ibaraki 305-8687, Japan. ${ }^{6}$ Department of Bioengineering, Nagaoka University of Technology, Nagaoka, Niigata 940-2188, Japan.

Published: 13 September 2011

\section{References}

1. Gierer J, Ljunggren S, Ljungquist P, Norén I: Reactions of lignin during sulfate pulping.18. The significance of a-carbonyl groups for the cleavage of $\beta$-aryl ether structures. Sven Papperstidn 1980, 83:75-82.

2. Gierer J, Norén I: Oxidative pretreatment of pine wood to facilitate delignification during kraft pulping. Holzforschung 1982, 36:123-130.

doi:10.1186/1753-6561-5-S7-056

Cite this article as: Ishikawa et al.: Introduction of alkali-labile units into lignin in transgenic plants by genetic engineering. BMC Proceedings 2011 5(Suppl 7):056.

\section{Submit your next manuscript to BioMed Central} and take full advantage of:

- Convenient online submission

- Thorough peer review

- No space constraints or color figure charges

- Immediate publication on acceptance

- Inclusion in PubMed, CAS, Scopus and Google Scholar

- Research which is freely available for redistribution

Submit your manuscript at www.biomedcentral.com/submit 